DOI https://doi.org/10.36059/978-966-397-158-2/83-102

\title{
THEORETICAL BACKGROUND OF THE RESEARCH OF THE TRANSITION TO DEMOCRACY PROCESS
}

\section{Myloserdna I. M.}

\section{INTRODUCTION}

The modern political world has been complex and controversial for thousands of years. The socio-political organization of human society was changing, mechanisms of interaction between peoples were updated and complicated. And since the legacy of the past is manifested in one way or another today, one can only understand events that take place in the political space by reference to their essence and content. One such event in the political world is the process of transition to democracy. The problem of the establishment and development of democratic foundations has been central to political science and has been addressed for a long time to a greater or lesser extent. In the 1980s and 1990s, the interest of researchers in the problems of democracy and the factors that caused it rose again. This is partly due to the fact that democratization, which took place in a number of regions of the world, was accompanied by trends not previously inherent in the formation of democracy. And thus, new political realities have created an additional impetus for researchers: a new subject area of analysis is formed, and thus the situation of controversy and reflection on new theoretical approaches to it.

We can agree with O.V. Babkina, who at the present stage of understanding the problems of the transition to democracy in political science is carried out in the framework of the transitological approach, which emerged during the neo-institutional turn of the 1980s-90s and the expansion of the theory of rational choice from economics to political science and social theory. The transitological paradigm focuses not on the objective conditions and preconditions of democracy, but on the activities of the main political actors - above all, the strategic choices and actions of political elites ${ }^{1}$.

1 Бабкіна О.В. Передумови переходу до демократії: ризики транзитивного суспільства. Науковий часопис НПУ імені М. П. Драгоманова. Серія 22. Політичні науки та методика викладання соціально-політичних дисциплін. 2015. Вип. 17. - С. 3-11. URL: http://enpuir.npu.edu.ua/bitstream/123456789/22598/1/Nchnpu_022_2015_17_3.pdf 
Consideration of the process of transition to democracy involves the study of the phenomenon of political transit as an object of scientific research and comparative analysis of models of the process of transition to democracy.

In the broad sense, the analysis of the modern meanings and the origin of the word «political transit» makes it possible to say that its content consists in the transformation of the totalitarian or authoritarian political-state system of the state towards the development of the general level of democracy in the state and society.

\section{The phenomenon of political transit as an object of scientific research}

The study of the phenomenon of political transit should begin with the observation that, according to some scholars, the «transitological paradigm» represents only a shy resurrection from the dead of the very theory of modernization that prevailed in the 1950's and 1960's, and the characteristic feature of which was the differentiation of the political structure (institutionalization), which envisaged the formation of an extensive network of socio-economic, political and other institutions of society aimed at ensuring stability and social order, but which in the 1970s revealed its intellectual bankruptcy ${ }^{2}$. In this case, the main feature of this situation is the disorder and decline of the types of knowledge used to understand and justify this worldview. It is precisely from these conditions that the concept of «political transit» emerged as a reflex to criticize the abstractness of modernization theory.

Political transit as a process began to be seen as the substantive essence of modernization, revealing the internal content in the political part. This is understood as political transit in the broad sense. In a more narrow and special sense, political transit in modern political science is the process of transitioning the state-political system from a less perfect in a democratic sense to a more sophisticated and advanced form of democracy, encompassing the political organization of society and the political system of the state. The phenomenon of global political transit is a so-called process of global democratization.

In the theoretical analysis of the phenomenon of political transit, one can agree with I.R. Khintba, who believes that in the development of political transitology it is decided to distinguish three stages: the end of the 1960's 1980 's - an analysis of societal transformations takes place, and the starting point is D. Rastow's work «Transitions to democracy: an attempt at a

\footnotetext{
2 Капустин Б. Г. Конец «транзитологии»? (О теоретическом осмыслении первого посткоммунистического десятилетия). Полис. Политические исследования. 2001. №4. С. 7.
} 
dynamic model»; the end of 1980-the second half of 1990 - an analysis of the fall of communist regimes in the USSR and the countries of Central and Eastern Europe, and among the leading scholars of this period it is worth noting S. Huntington and A. Pshevorsky; end of 1990 - present - analysis of transitional processes in certain countries of Central and Eastern Europe, which are ambiguous and lasting.

As S. Huntington points out, the history of society is such a stream of various events that different processes of political transformation do not have the capacity to self-distribute over strict historical temporal centers. In general, Huntington's approach makes it possible to understand in general terms the development of the process of global democratization and the extent of this phenomenon. Before researching the phenomenon of political transit, its constituents and features, it is necessary to pay attention to the methodological question of the study concerning the interaction of the concepts of «political transit» and «political transformation».

Literally, transformation (Latin - trans and formatio) means the modification or alteration of the appearance, shape, structure or essential properties and characteristics of an object. ${ }^{3}$ Political transformation means the acquisition by the political system of new features, changes in political standards and values; radical structural changes aimed at achieving a qualitatively new state of the system ${ }^{4}$. In the context of this study, political transit, unlike political transformation, is a broader process. Considering transit as a process of systemic transformation of the general spheres of society and the state as a whole, political transformation is seen as a major part of transit, encompassing mainly qualitative changes in the institutional and procedural mechanisms of functioning of the political system. It should be noted that this part of the transit is one of the most important. Based on this understanding of the two terms, they can be used in close relation as they reflect in a particular political segment and within separate time frames relatively similar political processes. According to the opinion of V.Ya. Gelman, justification for this approach may also be dictated by the fact that today, in search of an adequate interpretation of political changes in the CIS countries, transit theories are changing and transforming. The theorist also uses the terms «transit» and «transformation» as synonyms ${ }^{5}$.

${ }^{3}$ Современный словарь иностранных слов: около 20000 слов. СПб. Дуэт. Комета. 1994. С.617-618.

${ }^{4}$ Новейший политологический словарь / Д. Погорелый, В. Фесенко, К.Филиппов. Росто-на Дону. 2009. С. 241

${ }^{5}$ Гельман В.Я. Постсоветские политические трансформации (Наброски к теории). Полис. 2001. № 1. С. 20 
Thus, considering the differences of concepts, it is possible to speak meaningfully about the basic elements and characteristics of political transit, which is understood as intermediate quality, the transition of society from one position to another. In this approach, understanding political transit is reduced to defining the period of time by which the state-political system of the country and society itself undergoes fundamental transformation and coordinate changes. In a meaningful sense, political transit correlates with democratic reform of the system of political power and liberalization of the social and political life of the state.

According to the classical canons, five constituent elements of a political transit can be conditionally distinguished:

a) the preconditions for political transit, which are formed under conditions which are directly or relatively ahead of its inception. The preconditions of political transit, as one of the main components of its element, became of particular importance from the very beginning of the separation of transitology into an independent discipline of political science. So one of the «early transitologists», D. Rastow, suggested that «the only prerequisite is national unity» in the country. Of course, this unity is necessary because it is the basis for the reforms the state is going for. Unlike his followers, D. Rastow, in the question of the essence of national unity, was deeper, considering this unity as a community of the nation. He emphasized that «national rhetoric is most often heard from the mouth of those who are least confident in their sense of national identity» ${ }^{6}$. It should be noted that the assumptions of democracy include the acquisition of national unity and corresponding identity; achieving sufficiently high economic development, the widespread dissemination of such cultural norms and values that imply recognition of democratic principles, trust in major political institutions, citizenship and other. In addition, these prerequisites for political transit certainly have some universality, but the experience of transit states shows that not every prerequisite in the obligatory queue exists in all states where there are political transformations.

b) the starting point from which political transit as a process begins. Its presence is conditioned by the fact that the initial state of society is important, as it determines the nature and direction of transit. It is possible to start transit from a totalitarian state of society, but you can have an authoritarian regime with some elements of democracy as a starting point of transit. In this case, it is, first and foremost, that totalitarianism and authoritarianism serve as sort of starting points of transit in certain countries.

${ }^{6}$ Растоу Д. Переходы к демократии: попытка динамической модели. Полис. 1996. № 5. C.5-15. URL: http://read.virmk.ru/R/Rastou.htm 
Diversity and difficulties not least reveal some of the differences in political transit in authoritarian and post-totalitarian states.

Thus, if political transit has a starting point for a totalitarian regime, then its content in general parameters is characterized by the following aspects: dismantling the totalitarian system as a whole, since it is not capable of democratic change in its content; reforms can go both from above and from below; the opposition is rather artificial; There is an initial absence of civil society because totalitarianism is opposite to civil society, but since it acts as one of the conditions for successful political transit, its formation becomes a priority. In conditions where political transit has a starting point for authoritarianism, its content can be filled with the following aspects: authoritarianism is more pluralistic than totalitarianism; allows for the presence of elements of civil society that are necessary for democratization; transit has little risk of slipping into totalitarianism, while post-totalitarian transit has many chances of being interrupted by authoritarianism.

The selected component of political transit - the point of reference - in one way or another, for these forms, is general in nature and influences the whole process of transit.

c) the purpose of transit, that is, the state of society, the political system, the regime of power in which the transit takes place. As a goal of the transition period for transitional societies, most researchers call democracy, and therefore all discussions are centered on ways and means of achieving a democratic social order.

d) the transit process itself, with its specific content, which is determined by its internal stage and content characteristics. The fact is that assuming that consolidated democracy as a goal of political reform is to be achieved by the transit society at the final stage of the process, it is equally important to understand political transit as a sufficiently long and complex process which at different stages may have a gradual and reversed direction. In this sense, in many transitological concepts, political transit is seen as a step-bystep process, in which periods of liberalization, democratization, and the habit of democracy are consistently revealed. Consider the step-by-step and substantive characteristics of transit in more detail.

As researchers of political transit point out, the development of democracy requires not only some experience of democratic traditions, but also the most important, previous, at least not extensive experience of liberalism, even in monarchical or authoritarian form. It turns out that liberalism is a common basis for different types of democratic system of state and society. Thus, it can be stated that for all models of political transit 
the process of liberalization of the whole system of public relations is of great importance.

So O.V. Lukin, notes that I. Bjorlin, the outstanding theorist of liberalism. stressed that freedom exists more fully in the modes of enlightened liberalism than in democracies where the majority has the opportunity to impose its will on the minority. As O.V. Lukin writes, Western authors «have only recently seriously discussed that planting democracy on an unprepared ground not only does not increase the amount of freedoms, but may even help to eliminate the limited liberalism existing for democracy» ${ }^{7}$. It is worth noting that the distinction between these two concepts is fundamental, since democratization entails liberalization, but is a broader and specifically political concept, since it involves open competition for the right to control the government, which in turn allows for free elections that determine composition of the cabinet. Liberalization predominantly modifies the relationship between the state and civil society. And democratization basically disrupts the relationship between the state and political society as such. It is clear that liberalization does not necessarily have to transfer into forms of democratization ${ }^{8}$.

On a temporal scale, liberalism and democratization represent two phases of the overall process. Therefore, they are interdependent, and their sequence suggests that without prior liberalization, there can be no deep democratization of a transit society and democracy cannot be rooted in it. Liberalization is deepening and capturing all new spheres of the public relations system.

In this sense, political transit must be understood not only as a linear, one-dimensional process, but also as a three-dimensional process that develops horizontally and vertically. On this basis, it can be stated that the nature of the interconnection of the processes of liberalization and democratization in a meaningful way reveals the specifics of political transit. After the relatively successful implementation of a liberalizing and democratizing society by society, the process of political transit enters its last, final stage - socialization (consolidation).

In its classic version, this was reflected in the concept of political transit by G. O'Donnell and F. Schmitter, who distinguish the three stages of the transition to democracy from authoritarianism or totalitarianism:

7 Лукин А.В. Переходной период в России: демократизация и либеральные реформы. Полис. 1999. № 2. С. 140.

${ }^{8}$ Stepan A. Democratizing Brasil? Problems of Tranzition and Consolidation. N.Y. Oxford; Oxford University Press, 1989. P.78. 
1) liberalization; 2) democratization; 3) socialization ${ }^{9}$. According to their concept, the step-by-step essence of political transit is that it progressively evolves from «liberalization» to «democratization», with the subsequent deepening of democracy and assimilation by all social groups at the stage of «socialization», which ensures the transition to «sustainable democracy» as the ultimate goal of political transit.

Thus, it can be stated that the development of political transit is subject to the integral logic of transformation of the undemocratic regime into democracy, which was reproduced in the syntactic construction of political transit by O.G. Kharytonova. According to her design, «... the ideal type of transition to democracy is likely to consist of four main stages: 1) liberalization of political life, providing for the institutionalization of civil liberties, controlling the «opening» of the regime; 2) dismantling the most viable institutions of the previous political system; 3) democratization, which is characterized by the formation of the norms, procedures and institutions of the new democratic regime, is considered the main criterion to be free elections ... and the consolidation of the democratic political system; 4) re-socialization of citizens into a new system ${ }^{10}$. In general, in spite of some schematics, this approach of O.G. Kharytonova is relatively functional for the analysis of intra-transit stages.

e) a result that does not always coincide with its purpose. Moreover, in most cases during the «third wave of democratization» the goal is not achieved. Thus, it is not necessary that the transit will result in consolidated democracy. This is due to the fact that in addition to the above characteristics, political transit has such a significant feature as the uncertainty of its procedures and results. This view is, for example, expressed by F. Schmitter, who associates it with the possible threats to the democracies of states of so-called «connected democracies» ${ }^{11}$.

Researchers propose different ways out of uncertainty, among which one would like to point out A. Przeworski, who characterizes the transition to democracy as the «kingdom of uncertainty». Depending on the purpose and resources of the specific political forces and structures that emerged between them in the «uncertainty zone» of conflicts, A. Przeworski identifies five possible outcomes of the transition period: 1) when no democratic institute can assert itself and political forces begin to fight for a new dictatorship;

${ }^{9}$ О’Доннел Г. Делегативная демократия. Пределы власти. 1994. № 2/3. С. 7.

${ }^{10}$ Харитонова О.Г. Генезис демократии (Попытка реконструкции логики транзитологических моделей). Полис.-1996. №5. С.73-74.

${ }_{11}$ Шмиттер Ф. Процесс демократического транзита и консолидации демократии. Полис. 1999. №3. С.31 
2) when no democratic institution can assert itself and yet political forces agree on democracy as a temporary solution; 3) when the established democratic institutions might remain, but competing forces compete for the establishment of a dictatorship; 4) when, in the case of the introduction of some democratic institutions, they could survive, but the opposing political forces agree on a viable institutional structure; 5) when individual democratic institutions might remain, and when they are introduced, they are indeed strong. As can be seen from the list of possible outcomes of A. Przeworski's transition, variants of the final results of political transit, characterized by a high level of uncertainty, can vary over a wide range ${ }^{12}$.

Thus, an analysis of the theoretical views of theorists on the essence of political transit makes it possible to divide them into two groups: some authors emphasized structural factors (above all, state and national, socioeconomic, cultural and value conditions and prerequisites for democracy), and others - procedural factors (especially the choice and sequence of specific decisions and actions of those political actors on whom the democratization process depends).

Representatives of the structural approach identify major correlations between some socio-economic and cultural values and the likelihood of establishing and maintaining democratic regimes in different countries. Such correlations are understood as structural - that is, conditioned by the attention of certain objective structures, and not by the subjective intentions and actions of participants in the political process - the preconditions and conditions of democratization and democracy.

Such correlations are understood as structural - that is, conditioned by the attention of certain objective structures, and not by the subjective intentions and actions of participants in the political process - the preconditions and conditions of democratization and democracy ${ }^{13,14}$. They believe that the actions of political actors who initiate and make democratic transit are not even conditioned by their «objective» position in the public structure. On the contrary, their «subjective» choices themselves create new political opportunities.

It should also be noted that a theoretical and methodological synthesis of structural and procedural approaches to democratic transit is desirable for

12 Пшеворский А. Демократия и рынок. Политические и экономические реформы в Восточной Европе и Латинской Америке. / Пер. с англ. под ред.проф. Бажанова В.А.-М. : РОССПЭН. 1999. С. 222-225.

${ }^{13}$ О’Доннелл Г. Делегитивная демократия. Век XX и мир. 1994. №7. C.189-195 URL: http://old.russ.ru/antolog/predely/2-3/dem01.htm

14 Шмиттер Ф. Процесс демократического транзита и консолидация демократии. Полис. 1999. № 3. С. 30-33. 
political transit research, as it would allow for a broader set of factors and variables to be considered in the analysis and to build more multidimensional models of the processes studied. It can also be argued that finding a possible way to a primary synthesis of this kind may prove futile to have a specific methodology of analysis, first used in the classic work of D. Campbell and his colleagues «American Voter» and called the «causality funnel».

D. Campbell and his co-authors define this analytical methodology as follows: «Imagine a sequence of events, as if they were inside a cavern of causality.... Let us imagine that the funnel axis is this temporary dimension. The events are understood as if they were following one another in a sequence of convergent causal chains, moving from a wide part of the cone to its narrowing.

The funnel shape is the logical result of the task chosen to explain the task. Most of the complex events in the funnel are the result of numerous previous causes. Each of these events, in turn, affects many representations, but our focus of attention narrows as we approach variable dependent behavior. We are gradually eliminating those consequences that cease to influence political action. As we are forced to consider all partial causes as essential at all times, the implications for us are slightly less than their causes. The result is a convergence effect, a convergence at one point ${ }^{15}$. I will note that this methodology was modified for the analysis of tarsive processes of A.Yu. Melville, who noted that according to this methodology, the factors that influence the progress of democratic transit - from the initial liberalization of the regime to the launch of new democratic institutions and procedures - could be analyzed at the following seven conditional levels of variables:

1. External international environment (world economic situation, political and strategic relations), etc.;

2. State and national factors (a single territory and state, a sense of national identity, and the like) - as a condition and precondition for the movement itself to democracy;

3. General socio-economic level of development and modernization of society;

4. Socio-class processes and conditions (measure of differentiation and development of social structure of society);

5. Socio-cultural and value factors, that is, cultural and political values and orientations that dominate in society;

${ }^{15}$ Campbell A., Converse P., Miller W., Stokes D.. The American Voter. N.Y. 1960. 573 p. 
6. Political factors and processes (interaction of parties, socio-political movements and interest groups);

7. Individual, or personal, political and psychological factors (specific actions and volitional decisions of key political actors, as well as their «charismatic») ${ }^{16}$.

Of course, the following question arises: will the description of factors be systematized according to a multidimensional technique with a theoretical explanation adequate to the complexity of the phenomenon itself? Strictly speaking, no. The proposed use of the «causality funnel» methodology cannot replace other scientific pursuits for developing an integrated theory of democratic transit. And the proposed methodological model is only one of the possible ways to find explanations for the essence of the phenomenon of transition to democracy as such, but not these explanations themselves. This is, strictly speaking, the methodological contours of the study, the specific meaningful content of which - for each specific case - may be different.

\section{Comparative analysis of models of the process of transition to democracy}

The theoretical and methodological approaches to the study of political transit, discussed in the previous paragraph, allow us to consider the universal models by which this political phenomenon develops in the modern world. In this case, the model of political transit means a certain dynamic form within which a country or group of states makes the transition from undemocratic forms of administration and government to forms democratic and which reveals the parameters of the subsequent development of transit societies.

The very variety of possible means of political transit with many options for solving problems and problems arising in it, the limit variety of conditions in which the state enters transit, national peculiarities of experiencing painful transformations, inevitable during the transit period, determine the specifics of transit and dictate.

Most clearly this side of political transit is described by S. Huntington's concept, so let's analyze it in more detail. In Huntington's view, the transition to democracy is a process of step-by-step change in the configuration and nature of the interaction of major political actors in the political field of the state. After considering the empirical material, he

16 Мельвиль А.Ю. Опыт теоретико-методологического синтеза структурного и процедурного подходов к демократическим транзитам. Полис. 1998. № 2. С. 6-37 - URL: http://www.politnauka.org/library/dem/melvil.php 
identified three models of democratization of so-called countries of «the third wave».

The «transformation» process is a major model of transition, as 16 of the 35 «third wave» transit states have been democratized with this option. During the «transformation» period, the ruling elite of the transformative regimes plays a crucial role, since it actually initiated the fall of the previous regime and its change to a democratic one.

According to the opinion of S. Huntington, the «transformation» model of transition is typical for Spain and Brazil, and among post-communist countries - for Hungary. Being the most difficultly structured model of the transition to democracy, the process of «transformation» consists of five main phases, four of which are still under authoritarian regime: 1) the emergence of reformers; 2) the coming of the reformers to power; 3 ) contradictory liberalization; 4) consensus with conservatives; 5) co-opting the opposition ${ }^{17}$.

The first signs of the emergence of the first phase of transformation - the «emergence of reformers» - is the emergence of previous or real leaders, which in turn initiate the transition to democracy.

The advent of the second phase of transformation - the «coming of reformers to power» - in its content means the release of democratic reformers from their status of marginalized within authoritarian regimes and the acquisition of full political power. The very arrival of reformers to power marks the beginning of the third phase of transformation - «controversial liberalization».

According to the opinion of S. Huntington, the content of the third phase of transformation is characterized by the pursuit of liberal reforms in the society on the one hand, and the desire to preserve the stability of the liberalized authoritarian system on the other. In other words, in carrying out liberal reforms during this phase, reformers are in no hurry to carry out large-scale democratic reforms in order to preserve the existing authoritarian regime. As a result of such a two-pronged policy, liberal reformers become temporary figures in power, eventually leaving them and giving way to democratic reformers or conservatives.

The further development of the transformation process takes place in its fourth phase, the Consensus with Conservatives phase, which is due to the fact that gaining power allows reformers to start democratization, but does not deny conservatives the opportunity to challenge them. As S. Huntington points out, one of the main conclusions that reformers come to during the

${ }^{17}$ Huntington S. The Third Wave: Democratization in the Late Twentieth Century. Norman and London: University of Oklahoma Press., 1991. P. 235-236 
fourth phase of transformation is the inability to continue their democratic change without some retreat caused by the need to make concessions to the Conservatives.

The fifth phase of transformation - the phase of «co-opting the opposition», according to S. Huntington is characterized by the entry into the political advance of a political force that opposes the reformist regime. At the level of this phase of transformation, the ruling reform elite is losing the possibility of full control of the situation and, as a result, is forced to engage in real dialogue with the opposition.

S. Huntington's second model of democratization of the «third wave» countries - the «replacement» model - is a process very different from the «transformation». It involves three distinct stages: 1) the struggle for the fall of the regime; 2) the fall of the regime; 3) fight after the fall of the regime.

According to the opinion of S. Huntington, until 1990 in the states of the «third wave of democratization» political transformation was under the option of «replacement» only in 6 cases. At the same time, «replacement» was rare in the transition from one-party systems and military regimes and more common in the transition from personal dictatorships.

The third model of the democratic «third power» holder of S. Huntington is the «permutation» model, which is a process that performs the activity between «transformation» and «replacement». In a «reshuffle», the process of democratic political regime is the result of sharing real elites and opposition. At the same time, in the ruling elite, the balance between conservatives and reformers is that it is ready to contemplate regime change, but is not ready to initiate it, as is the case with the replacement model. Thus, the ruling elite must be pushed to formal or informal negotiations with the opposition. According to the opinion of S. Huntington, approximately 11 out of 35 cases of liberalization or democratization fit the model of «permutation». Among them are Poland, Czechoslovakia, Uruguay and others.

The above typological models of S. Huntington's political transit have an undeniable interest, despite the fact that he constructed them on the basis of the processes of global democratization that were characteristic of the 1990s.

It should be noted that the ideas of A. Przeworski, which considers two stages of political transit: liberalization and democratization, are close to the Huntington`s concept. At the same time, it also differentiates the stage of democratization into three stages: «liberation», «construction» and «rivalry». The peculiarity of A. Przeworski's approach is his emphasis on the content and disclosure of the internal conditions of behavior of the parties involved in the interaction during the transit. 
The stage of liberalization of political transit, which is characterized by instability, can take place in two directions, from above or below, depending on what appears before and brightly - a split in the leadership or the force of the mass movement. Liberalization can both bring about change and provoke repression, that is, a return to the strengthening of the previous authoritarian regime. In the event that the changes continue, the next stage of political transit - democratization - will take place, with its first stage of «liberation» from the authoritarian regime. Releasing from the heightened pressure of authoritarianism can be peaceful enough as a result of compromise, forging a mutual understanding between reformers in the middle of an authoritarian bloc and moderate ones in the middle of the opposition. According to A. Przeworski, such a compromise is possible under three conditions: if the reformers and the moderate ones agree on democratic institutions in which the social groups represented by them would have an influence; if reformers can coerce or neutralize solid line supporters; if moderate are able to control radicals in the opposition. At the same time, the latter two conditions logically warn the first, since they determine the possible actions of reformers and moderate.

The second successive stage of democratization - the «construction» of democracy, occurs through negotiation and which can be realized by three options of development: 1) the balance of forces known and inequalities; 2) the balance of forces known and equilibrium; 3) the balance of forces is unknown.

The third successive stage of democratization - the «rivalry», of those who are fighting against authoritarianism goes through pacting, agreement between leaders of political parties. According to A. Przeworski, the goal of such pacts is to protect embryonic democratic institutions by reducing the incidence of conflicts arising from the political course and recruitment in a particular transit society ${ }^{18}$.

In addition to S. Huntington and A. Przeworski, clear examples of a staged model of political transit are reflected in the concept of D. Rostow, who considers the process of democratization in large blocks, according to which political transit goes through three phases: 1) «preparatory», which is a mandatory prerequisite - the existence of national unity, which can take place in prehistoric times, as in Japan and Sweden; may be ahead of other stages of the transition to democracy for centuries, as in France. It is also necessary to create the constitutional laws or parliamentary practices of a

${ }^{18}$ Пшеворский А. Демократия и рынок. Политические и экономические реформы в Восточной Европе и Латинской Америке./Пер. с англ. под ред.проф. Бажанова В.А. - М. : РОССПЭН. 1999. С.230-231 
pre-existing democracy within this phase, but the theorist immediately noted that it is important to create institutions independently, since copying them alone will not produce the desired result; 2) a «decision-making phase» that plays a large role in a transitional society, and democratic decision-making in some sense can be seen as an act of conscious, openly-revealed consensus. In addition, decision-making should be shifted to the level of professional politicians and the general population; 3 ) an «addictive phase» that assumes that democracy is inherently a competitive process, and in the course of competition, preferences are given to those who can rationalize their commitment to the new system, and even more are - those who genuinely believe in it ${ }^{19}$.

Given the fact that the typological models of the transition to democratization of the aforementioned political scientists were designed by them, based on the realities of the period of global democratization until the 1990s, we can give an example of a typological model of the transition to democracy, which was developed under the influence of 1989 events in the countries Central and Eastern Europe. It is an idealistic model for the democratization of T. Karl and F. Schmitter, who view it from the point of view of a formal transition. In their models, the authors identified two main transition parameters: leading actors in the transition process (elite and masses) and actors strategies in the transition process (compromises and power $)^{20}$. Depending on the combination of these parameters, they have identified four models of the transition to democracy: the «model of the pact transition», according to which the main actors are the elites, the strategy is a compromise character. An example of such a model is Spain's political transformation process; a «model of reformist transition», in which the main actors are the masses, whose strategy is a compromise character. An example is the political transformation of Czechoslovakia in 1989; a «model of revolutionary transition», in which the main actors are the masses, who in turn use power strategies. This model was implemented in Russia in 1917; A «coupled transition model» where the main actors are the elite who use power strategies. This model was quite successfully implemented in Brazil in the period of 1974-1985s.

The advantages of one or the other of these transition models vary. T. Karl and F. Schmitter point out that the transition to democracy by the

${ }^{19}$ Растоу Д. Переходы к демократии: попытка динамической модели. Полис. 1996. № 5. C. 5-15. - URL: http://read.virmk.ru/R/Rastou.htm

${ }^{20}$ Карл Т., Шмиттер Ф. Пути перехода от авторитаризма к демократии в Латинской Америке, Южной и Восточной Европе. Международный журнал социальных наук. 1994. № 1. C. 30 . 
models of «revolutionary» and «forced transition» is not usually conducive to democracy. The «reformist transition» model rarely leads to a stable consolidated democracy. The ideal form of transition is depicted by the «pact transition» model when there is an explicit or implicit agreement between «democrats», a moderate part of the opposition and representatives of other segments of the ruling group ${ }^{21}$. And more transitologists agree with the preference for a «pact transition» to democracy.

According to the opinion of V.Ya. Gelman, analysis of these models makes it possible to confirm that, depending on the relation of forces between the leading actors of the political process, several models of transition to democracy can be distinguished and «they are basically reduced to three options: transformation, by which the process of democratization is carried out by the previous ruling elites; the substitution resulting from the collapse of the authoritarian regime and the process of democratization is carried out by the opposition that has come; a mixed version of the process of democratization as a result of the combined actions of the elites and the opposition $^{22}$.

In view of the above, it is expedient to go beyond the system of classification of political transformation models in the analysis of typological models of political transit and to consider these models on the basis of a number of approaches. The adopted classification system allows to group the transition models of the transit countries of the «third wave of democratization» by those attributes of political transit that are characteristic for each of them. This system of classifications includes a number of quantitative and qualitative and formally meaningful approaches in modeling the transformation of the political system and allows to identify 6 typological models of political transit, each of which has in its midst different variants of implementation:

- a dynamic model of transit, the implementation options of which vary in the pace of democratic transformation (in some countries, including Poland, Hungary, the transition to democracy can be characterized as a forced, and the key to the success of democratic transformations is the presence of economic and socio-cultural preconditions, historical experience of functioning democratic institutions. However, in some Latin American countries, a different scenario of transition to democracy was characteristic a «changeover» variant that included periods of forced change with periods

\footnotetext{
${ }^{21}$ ibid, C. 31-33

${ }^{22}$ Гельман В.Я. Трансформации в России: политический режим и демократическая оппозиция. - М.:МОНФ., 1999. С. 21
} 
of stoppages and reversals, as a result of alternating military or authoritarian regimes);

- a meaningful transit model, the implementation options of which differ in the content of the transition process (so we can speak of a «complex transition» of states, which was characterized by simultaneous economic, political reforms and creation of its independent statehood, that is, carried out a complex transformation. But there were also countries in which development was carried out with the displacement or change of only political system - Spain, Portugal, or changes of purely economic reforms countries of East and Southeast Asia);

- a formal transit model, implementation options differ in the forms of democratic transition: more or less peacefully (such states include those in which the so-called «velvet revolutions» took place - Czech Republic, Bulgaria, Hungary), the transition to democratic rule was the result of intense internal confrontation and struggle by the elites. (Russia), a revolutionary form of transition to democracy (in Latin American countries «... characterized by a sharp liberalization from above, a radical replacement of the political elite, the devastating collapse of the previous regime, democratization from the top and forced socialization. Moreover, such a path of transition is characterized by greater instability, unpredictability and the ability to roll back to a previous, authoritarian system ${ }^{23}$ ).

- a conditioned transit model, implementation options of which differ in the determinants of democratic reform, i.e. the impetus for democratization were external or internal factors, or both.

- a large-scale model of transit, the implementation options of which vary in the scope of citizen involvement in the democratic process (one can observe a mass transition involving large sections of the population, an elitist transition and an intergroup that is under the influence of competition and struggle of several political groups).

- a model of institutional preconditions, the implementation options of which differ in the presence of institutional preconditions of democratization processes in the countries (within this model it is possible to state the initial transition to democracy, which was typical for states that did not have experience of the existence of classical democratic institutions, the secondary transition to democracy, which envisaged the presence in the historical past of democratic and liberal institutions and the aborted transition characterized by the existence of previously certain elements of

${ }^{23}$ Гельман В.Я. Как выйти из неопределенности. Pro et Contra. 1998. Т. 3. № 3. С. 25. 
democratic topics but which were destroyed during the formation of antidemocratic regimes).

Thus, it can be concluded that the separation of models of the transition to democracy is proved by the fact that the transition to democracy in different states is, to a certain extent, conditional, since it is not possible to adjust «unambiguously» the political transformation of the states of one region or even a single country into a framework of strictly defined typological scheme. This will go against the very dialectical process of democratic transit. In the context of the above, we can agree with the opinion of G.I. Weinstein, who emphasizing the importance of analyzing current processes of political transformation in terms of the growth of typological diversity of modern democracy, points out that there are some considerations to be made: «Firstly, the considerable complexity of developing the categorical definitions necessary to describe the typological diversity of democracies should be noted. Secondly, it is necessary to note the essential analytical difficulties of the organic combination of qualitative evaluation of a «new democracy» with its meaningful characteristic» ${ }^{24}$.

\section{CONCLUSIONS}

A comprehensive analysis of the theoretical foundations of the study of the transition to democracy has led to the following conclusions:

«Transit» is to be understood as a transition that develops in a broken pattern, a process that does not always have a positive dynamic and does not always end with the consolidation of democratic institutions and procedures.

It has been established that the development of democracy requires not only some experience of democratic traditions, but also a previous, at least not extensive experience of liberalism, even in monarchical or authoritarian form. It turns out that liberalism is a common basis for different types of democratic system of state and society. Thus, it can be stated that for all models of political transit the process of liberalization of the whole system of public relations is of great importance.

It is determined that the process of political transit includes five main components: initial prerequisites; starting point of reference; goal; the transit process itself and the transit summary. The nature of each of these parameters determines, after all, the specificities of political transit in a particular transitional society.

${ }^{24}$ Вайнштайн Г.И. Российский транзит в контексте глобальной демократизации. Международная экономика и международные отномения. 2000. № 10. С. 81. 
The analysis of classical models of political transit (D. Rostow, L. Diamond, F. Schmitter and G. O'Donnell, S. Huntington) allowed us to consider this process in different focuses. Composing a single process of progressing from a totalitarian state to a liberal democracy, the diagrams of the transit model reflect the diversity of the parties to this process and make it possible to say that one of the main essential characteristics that determines the specifics of political transit is the significant uncertainty of its procedures and results. And the high level of uncertainty of political transit causes a considerable variability in the ways out of this uncertainty at the end of transit.

\section{SUMMARY}

The article provides a comprehensive analysis of the theoretical background of the research of the transition to democracy, which provides for the study of the political transit phenomenon as an object of scientific research and a comparative analysis of models of the transition to democracy process.

The essence of the concept of «political transit» is revealed and its main constituent elements are distinguished. It is established that political transit should be understood not only as a linear, one-dimensional process, but also as a three-dimensional process.

It has been shown that, on a time scale, liberalism and democratization represent two phases of the overall process. Therefore, they are interdependent, and their consistency suggests that without prior liberalization, there can be no deep democratization of a transit society and democracy cannot be rooted in it.

The essence of the concept of «political transit model» is determined and classical models of political transit are analyzed (D. Rostow, L. Diamond, F. Schmitter and G. O'Donnell, S. Huntington). It is established that the transition to democracy in different states is, to a certain extent, conditional, since it is impossible to «adjust» unambiguously the political transformation of the states of one region or even of a single state within a strictly defined scheme.

\section{REFERENCES}

1. Бабкіна О.В. Передумови переходу до демократії: ризики транзитивного суспільства. Науковий часопис НПУ імені М. П. Драгоманова. Серія 22. Політичні науки та методика викладання сочіально-політичних дисииплін. 2015. Вип. 17. С. 3-11. URL: 
http://enpuir.npu.edu.ua/bitstream/123456789/22598/1/Nchnpu_022_2015_1 7_3.pdf

2. Вайнштайн Г.И. Российский транзит в контексте глобальной демократизации. Международная экономика и международные отношения. 2000. № 10. С. 78-89.

3. Гельман В.Я. Как выйти из неопределенности. Pro et Contra. 1998. Т. 3. № 3. С. 21-39.

4. Гельман В.Я. Постсоветские политические трансформации (Наброски к теории). Полис. 2001. № 1. С. 15-29.

5. Гельман В.Я. Трансформации в России: политический режим и демократическая оппозиция. - М.:МОНФ., 1999. 240 с.

6. Карл Т., Шмиттер Ф. Пути перехода от авторитаризма к демократии в Латинской Америке, Южной и Восточной Европе. Международный журнал соииальных наук. 1994. № 1. С. 29-46.

7. Лукин А.В. Переходной период в России: демократизация и либеральные реформы. Полис. 1999. №2. С.134-154.

8. Мельвиль А.Ю. Опыт теоретико-методологического синтеза структурного и процедурного подходов к демократическим транзитам. Полис. 1998. № 2. С. 6-37. URL: http://www.politnauka.org/ library/dem/melvil.php

9. Новейший политологический словарь / Д. Погорелый, В. Фесенко, К. Филиппов. Росто-на Дону. 2009. 318 с.

10. О’Доннелл Г. Делегативная демократия. Предель власти. 1994. № 2/3. С. 5-15.

11. О’Доннелл Г. Делегитивная демократия. Век XX и мир. 1994. №7. C.189-195 URL: http://old.russ.ru/antolog/predely/2-3/dem01.htm

12. Пшеворский А. Демократия и рынок. Политические и экономические реформы в Восточной Европе и Латинской Америке. / Пер. с англ. под ред.проф. Бажанова В.А.-М.:РОССПЭН.-1999.-320 с. C. 222-225.

13. Растоу Д. Переходы к демократии: попытка динамической модели.// Полис. 1996. № 5. С. 5-15. URL: http://read.virmk.ru/R/ Rastou.htm

14. Современный словарь иностранных слов: около 20000 слов. СПб. Дуэт. Комета. 1994. 752 с.

15. Харитонова О.Г. Генезис демократии (Попытка реконструкции логики транзитологических моделей). Полис. 1996. № 5. C. 70-78.

16. Хинтба И.Р. Три этапа эволюции транзитологии: на пути к четвертому? Вестник РУДН, серия Политология 2008 № 2. С. 20-34. 
17. Шмиттер Ф. Процесс демократического транзита и консолидации демократии. Полис. 1999. № 3. С. 30-33.

18. Campbell A., Converse P., Miller W., Stokes D.. The American Voter. N.Y. 1960.573 p.

19. Huntington S. The Third Wave: Democratization in the Late Twentieth Century.-Norman and London: University of Oklahoma Press., $1991.366 \mathrm{p}$.

20. Stepan A. Democratizing Brasil? Problems of Tranzition and Consolidation. N.Y. - Oxford; Oxford University Press, 1989404 p.

\section{Information about the author:}

Myloserdna I. M.,

$\mathrm{PhD}$ in Political Sciences, Associate Professor, Associate Professor at the Department of Political Theories of the National University «Odessa Law Academy» 2, Academichna str., Odesa, 65009, Ukriane 